\title{
The Microstructure and Capacitance Characterizations of Anodic Titanium Based Alloy Oxide Nanotube
}

\author{
Po Chun Chen, ${ }^{1}$ Sheng Jen Hsieh, ${ }^{2}$ Chien Chon Chen, ${ }^{3}$ and Jun Zou ${ }^{1}$ \\ ${ }^{1}$ Department of Electrical Engineering, Texas A\&M University, College Station, TX 77843-3128, USA \\ ${ }^{2}$ Department of Engineering Technology, Texas A\&M University, College Station, TX 77843-3367, USA \\ ${ }^{3}$ Department of Energy Engineering, National United University, Miaoli 36003, Taiwan
}

Correspondence should be addressed to Chien Chon Chen; chentexas@gmail.com and Jun Zou; junzou@ece.tamu.edu

Received 15 April 2013; Accepted 18 June 2013

Academic Editor: Anukorn Phuruangrat

Copyright (C) 2013 Po Chun Chen et al. This is an open access article distributed under the Creative Commons Attribution License, which permits unrestricted use, distribution, and reproduction in any medium, provided the original work is properly cited.

\begin{abstract}
This paper presents a simple anodization process to fabricate ordered nanotubes (NTs) of titanium and its alloys (Ti-Mo and Ti-Ta). $\mathrm{TiO}_{2}, \mathrm{MoO}_{3}$, and $\mathrm{Ta}_{2} \mathrm{O}_{5}$ are high dielectric constant materials for ultracapacitor application. The anodic titanium oxide contains a compact layer on the NT film and a barrier layer under the NT film. However, the microstructure of oxide films formed by anodic Ti-Mo and Ti-Ta alloys contains six layers, including a continuous compact layer, a continuous partial porous layer, a porous layer, a net layer, an ordering NT film, and an ordering compact barrier layer. There are extra layers, which are a partial porous layer and a porous layer, not presented on the $\mathrm{TiO}_{2} \mathrm{NT}$ film. In this paper, we fabricated very high surface area ordered nanotubes from $\mathrm{Ti}$ and its alloys. Based on the differences of alloys elements and compositions, we investigated and calculated the specific capacitance of these alloys oxide nanotubes.
\end{abstract}

\section{Introduction}

The demands for energy storage and energy generation are increasing rapidly with the global energy crisis. Ultracapacitor is a technology for energy storage with advantages of low cost and high efficiency. Barium titanate $\left(\mathrm{BaTiO}_{3}\right)$, which exhibits a very high dielectric constant, is a good material for ultracapacitor fabrication [1-4]. However, the processes of producing $\mathrm{BaTiO}_{3}$, such as hydrothermal treatment [5, 6], metal-organic process [7], alkoxide hydrolysis [8, 9], RF sputtering [10], and sol-gel process [11], have been reported and they are very complex and costly. Titanium dioxide $\left(\mathrm{TiO}_{2}\right)$ can be formed nanotube by one-step anodizing process compared with the complex processes fabricating $\mathrm{BaTiO}_{3}$. However, the dielectric constant of $\mathrm{TiO}_{2}$ is not as high as $\mathrm{BaTiO}_{3}$, but $\mathrm{TiO}_{2}$ nanotube could be an ideal dielectric template due to its high surface area. A typical $\mathrm{TiO}_{2}$ nanotube fabrication can be achieved by anodization[12], and the ordered channel array of anodic titanium oxide nanotubes is able to serve as multiple parallel dielectric layers for the ultracapacitor.
On the other hand, metals ( $\mathrm{Al}$ [13], Hf [14], $\mathrm{Nb}$ [15], $\mathrm{Ta}$ [16], $\mathrm{W}$ [17], and $\mathrm{V}$ [18]) and alloys (Ti-Mo [19], Ti-W [20], Ti-Nb [21], Ti-V [22], Ti-Zr [23], Ti-Ta [24], and TiAl [25]) have been reported that they can also be formed high surface area of nanoporous oxide film. $\mathrm{WO}_{3}, \mathrm{Ta}_{2} \mathrm{O}_{5}$, and $\mathrm{TaTiO}_{3}$, which have higher dielectric constants than $\mathrm{TiO}_{2}$, of 1000 [26], 110 [27], and 200 [28], are the alternate dielectric materials for ultracapacitor. Unfortunately, they cannot form nanotubes structures as good as $\mathrm{TiO}_{2}$ nanotubes. Thus, in this paper, we used a simple process of anodization to fabricate $\mathrm{TiO}_{2}, \mathrm{TiO}_{2}-\mathrm{MoO}_{3}$, and $\mathrm{TiO}_{2}-\mathrm{Ta}_{2} \mathrm{O}_{5}$ nanotubes. Their high dielectric constants and large surface areas are very useful materials to build ultracapacitors. Based on the nanotube structural properties, such as diameter, porosity, and length, we also investigated the specific capacitances of the different titanium alloys.

\section{Experimental Procedure}

An ordered channel array of anodic titanium and titanium alloy oxides was fabricated by anodizing Ti, Ti-10Ta (90 wt.\% 


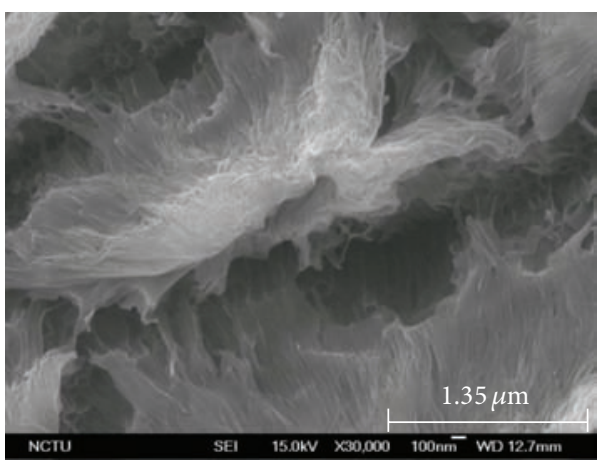

(a)

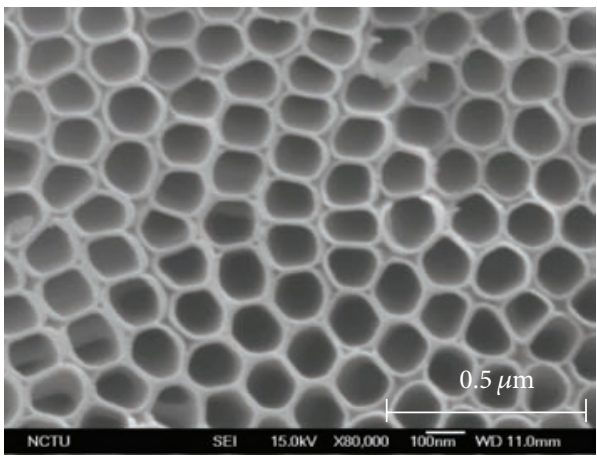

(c)

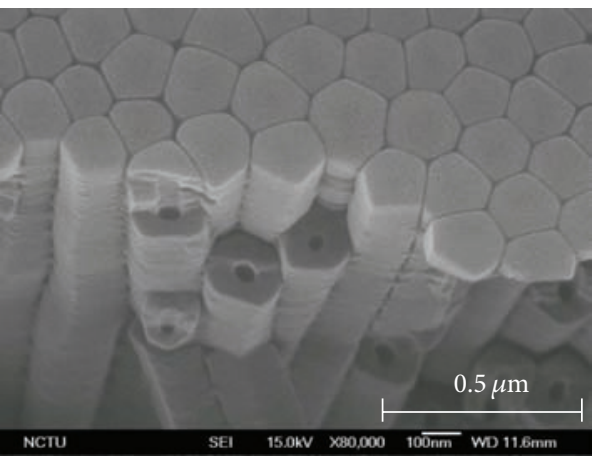

(e)

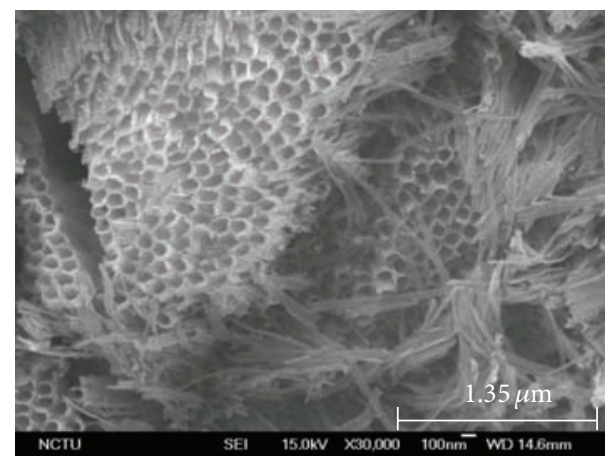

(b)

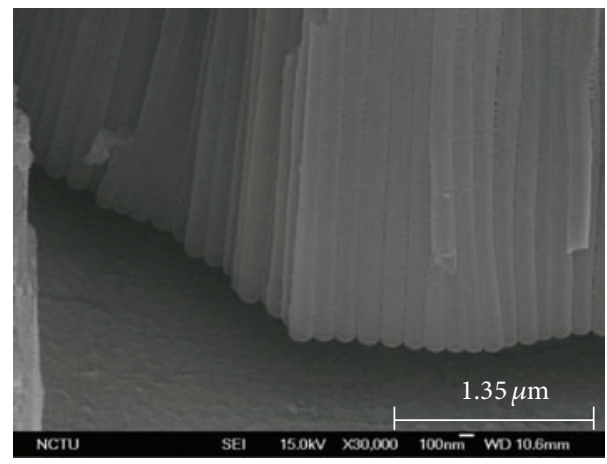

(d)

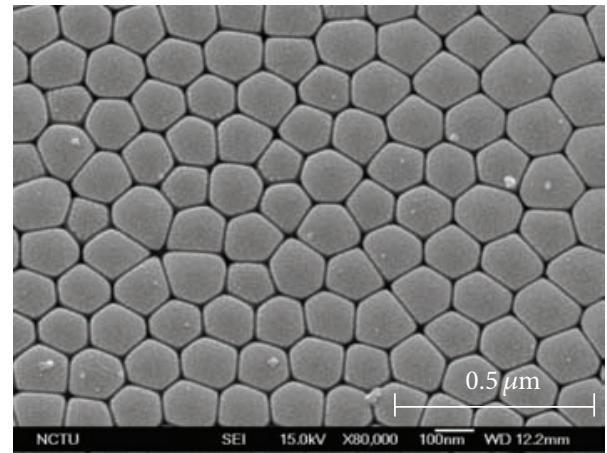

(f)

FIGURE 1: SEM images of $\mathrm{TiO}_{2} \mathrm{NT}$ : (a) an unwanted film cover on $\mathrm{TiO}_{2} \mathrm{NT}$, (b) partial unwanted film removed, (c) all unwanted films removed and $\mathrm{TiO}_{2}$ NT presented, (d) $\mathrm{TiO}_{2}$ NT side view, (e) $\mathrm{TiO}_{2}$ NT bottom view, and (f) a barrier layer on the $\mathrm{TiO}_{2} \mathrm{NT}$ bottom.

$\mathrm{Ti}+10$ wt.\% Ta), Ti-20Ta (80wt.\% Ti + 20 wt.\% Ta), and Ti-10Mo (90 wt.\% Ti + 10 wt. \% Mo) alloys. The metal substrates were first put through electropolishing (EP). The EP electrolyte included 5 vol. \% perchloric acid $\left(\mathrm{HClO}_{4}\right), 53$ vol.\% ethylene glycol monobutylether $\left(\mathrm{HOCH}_{2} \mathrm{CH}_{2} \mathrm{OC}_{4} \mathrm{H}_{9}\right)$, and 42 vol.\% methanol $\left(\mathrm{CH}_{3} \mathrm{OH}\right)$. EP processes of $\mathrm{Ti}$ and $\mathrm{Ti}$ alloys were conducted at $15^{\circ} \mathrm{C}$ under $52 \mathrm{~V}$ for 1 minute and $28 \mathrm{~V}$ for 13 minutes with platinum as a counter electrode at a constant stirring rate of $200 \mathrm{rpm}$. After EP, the samples were etched in 5 vol.\% HF for 5 min to form an additional thin anodic film on the metal substrates. $\mathrm{TiO}_{2}, \mathrm{TiO}_{2}-\mathrm{Ta}_{2} \mathrm{O}_{5}$, and $\mathrm{TiO}_{2}-\mathrm{MoO}_{3}$ nanotubes were anodized in an electrolyte of 0.5 wt.\% ammonium fluoride $\left(\mathrm{NH}_{4} \mathrm{~F}, 99.9 \%\right)$ and $2 \mathrm{wt} . \%$ $\mathrm{H}_{2} \mathrm{O}$ in ethylene glycol $\left(\mathrm{C}_{2} \mathrm{H}_{4}(\mathrm{OH})_{2}\right)$ solvent at a constant voltage of $60 \mathrm{~V}$ for 2 hours. After anodic films were formed by anodization, the films were then annealed in an air furnace at $450^{\circ} \mathrm{C}$ for 1 hour for crystallization. The surface morphologies of the anodic oxides were observed by using a scanning electron microscope (SEM, FEI Quanta 600). The alloy oxide nanotubes compositions can be analyzed by Energy Dispersive Spectrometer (EDS) (Oxford).

Cyclic voltammetry $(\mathrm{CV})$ performances were evaluated by an electrochemical analyzer ( $\mathrm{CH}$ Instruments, Model 600B, USA) using a standard three-electrode cell system with platinum as a counter electrode and silver-silver chloride electrode $(\mathrm{Ag} / \mathrm{AgCl})$ as a reference electrode in $0.5 \mathrm{M} \mathrm{H}_{2} \mathrm{SO}_{4}$ solution at room temperature. The $\mathrm{CV}$ scan rate was set as $20 \mathrm{mV} / \mathrm{s}$ in a potential range of $0 \mathrm{~V}$ to $0.9 \mathrm{~V}(\mathrm{Ag} / \mathrm{AgCl})$. 


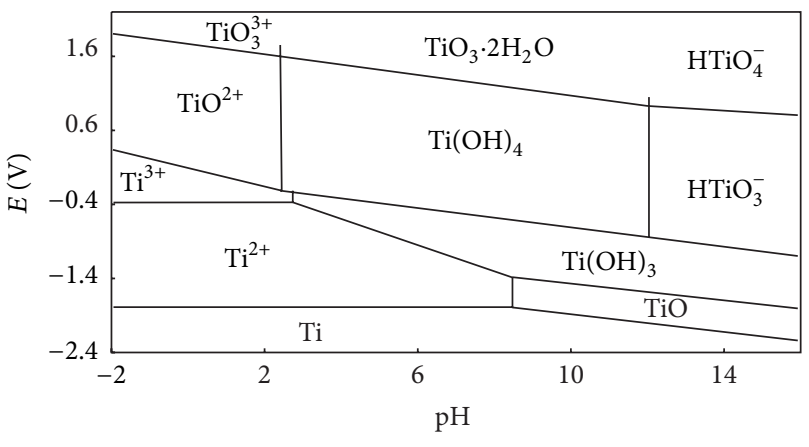

(a)

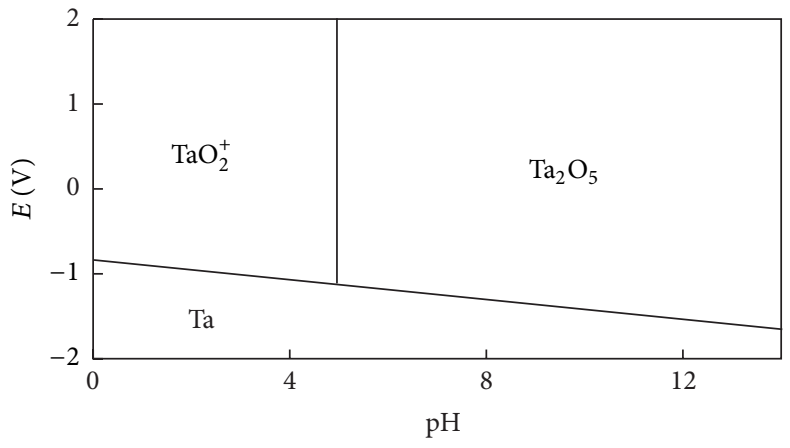

(b)

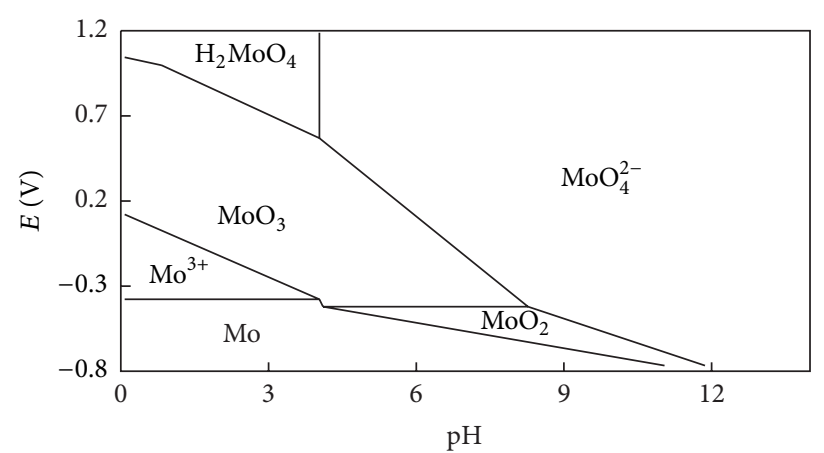

(c)

Figure 2: Pourbaix diagrams of (a) Ti, (b) Ta, and (c) Mo.

\section{Results and Discussion}

Figure 1 presents the SEM images of long-range ordered nanochannel $\mathrm{TiO}_{2} \mathrm{NT}$ structures formed by anodizing pure Ti foil: (a) an unwanted film covered on $\mathrm{TiO}_{2} \mathrm{NT}$, (b) partial unwanted film removed, (c) all unwanted films removed and the top view of $\mathrm{TiO}_{2} \mathrm{NT}$, (d) side view of $\mathrm{TiO}_{2} \mathrm{NT}$, (e) bottom view of $\mathrm{TiO}_{2} \mathrm{NT}$, and (f) a barrier layer under the $\mathrm{TiO}_{2} \mathrm{NT}$. $\mathrm{TiO}_{2}$ NT feature a pore diameter $\sim 120 \mathrm{~nm}$, pore density $\sim 8$ $\times 10^{9}$ pores $/ \mathrm{cm}^{2}$, and wall thickness $\sim 25 \mathrm{~nm}$; the length of the NT can be controlled from several $\mu \mathrm{ms}$ to hundred $\mu \mathrm{ms}$ with different types of the electrolytes (e.g., $\mathrm{NH}_{4} \mathrm{~F}$ ) and the anodization times at a constant applied voltage (e.g., $60 \mathrm{~V})$.

Immersing titanium in electrolyte causes complex reactions with 16 forms of Ti ions and oxides [29]. The Pourbaix diagram is useful to simplify the complex reactions [30]. Based on the Pourbaix diagram of $\mathrm{Ti}$ (Figure 2(a)), $\mathrm{TiO}^{2+}$ ion is a favorite formation when $\mathrm{pH}$ value is lower than 2.3 and voltage is higher than $-0.2 \mathrm{~V}(\mathrm{SHE})$ at $25^{\circ} \mathrm{C}$. $\mathrm{TiO}^{2+}$ can further react with $\mathrm{H}_{2} \mathrm{O}$ to from $\mathrm{Ti}(\mathrm{OH})_{4}$ which is anodic titanium oxide. Similarly, Ta Pourbaix diagram (Figure 2(b)) shows that $\mathrm{TiO}^{2+}$ is formed and converted to $\mathrm{Ta}_{2} \mathrm{O}_{5}$ under the condition of $\mathrm{pH}<5.1$ and applying voltage $>-1.2 \mathrm{~V}(\mathrm{SHE})$ at room temperature. Also Mo Pourbaix diagram (Figure 2(c)) implies that $\mathrm{Mo}^{3+}$ can be produced and form $\mathrm{MoO}_{3}$ in the condition of $\mathrm{pH}$ being below 4.2 and voltage being higher than $-0.35 \mathrm{~V}(\mathrm{SHE})$ at $25^{\circ} \mathrm{C}$. However, anodic $\mathrm{TiO}_{2}, \mathrm{MoO}_{3}$, and $\mathrm{Ta}_{2} \mathrm{O}_{5}$ can be formed in the neutral $\mathrm{pH}$ value electrolyte when it contains halogen element in it.
Anodization of titanium forms close-packed and verticalaligned nanotubes in a nonaqueous organic polar electrolyte with $\mathrm{F}^{-}$ions and minimizing water content. These electrochemical processes can be described as follows [31-34]:

$$
\begin{gathered}
\mathrm{Ti} \longrightarrow \mathrm{Ti}^{4+}+4 \mathrm{e}^{-} \\
\mathrm{H}_{2} \mathrm{O} \longrightarrow 2 \mathrm{H}^{+}+\mathrm{O}^{2-} \\
\mathrm{Ti}^{4+}+2 \mathrm{O}^{2-} \longrightarrow \mathrm{TiO}_{2} \\
\mathrm{Ti}^{4+}+2 \mathrm{H}_{2} \mathrm{O} \longrightarrow 4 \mathrm{H}^{+}+\mathrm{TiO}_{2} \\
6 \mathrm{~F}^{-}+\mathrm{TiO}_{2}+4 \mathrm{H}^{+} \longrightarrow\left[\mathrm{TiF}_{6}\right]^{2-}+2 \mathrm{H}_{2} \mathrm{O} \\
{\left[\mathrm{TiF}_{6}\right]^{2-}+n \mathrm{H}_{2} \mathrm{O} \longrightarrow\left[\mathrm{TiF}_{6-n}(\mathrm{OH})_{n}\right]^{2-}+n \mathrm{H}^{+}+n \mathrm{~F}^{-}} \\
{\left[\mathrm{TiF}_{6-n}(\mathrm{OH})_{n}\right]^{2-}+(6-n) \mathrm{H}_{2} \mathrm{O}} \\
\longrightarrow\left[\mathrm{Ti}(\mathrm{OH})_{6}\right]^{2-}+(6-n) \mathrm{H}^{+}+(6-n) \mathrm{F}^{-} \\
{\left[\mathrm{Ti}(\mathrm{OH})_{6}\right]^{2-}+2 \mathrm{H}^{+} \longrightarrow \mathrm{TiO}_{2}+4 \mathrm{H}_{2} \mathrm{O}}
\end{gathered}
$$

During anodization, there are oxidation reactions at the interface between metal and electrolyte. $\mathrm{Ti}^{4+}$ is formed and the water in the electrolyte is decomposed, reactions (1) and (2). $\mathrm{TiO}_{2}$ is then formed between the metal and the electrolyte through ion migration, reactions (3) and (4). $\mathrm{F}^{-}$ions etch the $\mathrm{TiO}_{2}$ forming $\left[\mathrm{TiF}_{6}\right]^{2-}$ and then combine with the $\mathrm{H}_{2} \mathrm{O}$ to form $\left[\mathrm{TiF}_{6-n}(\mathrm{OH})_{n}\right]^{2-}$, reactions (5) and (6). Because the $\mathrm{F}^{-}$ ions are doped in the $\mathrm{TiO}_{2}$ but do not form a compound, reaction (6) can be rewritten as (7). Finally, $\left[\mathrm{Ti}(\mathrm{OH})_{6}\right]^{2-}$ reacts with $2 \mathrm{H}^{+}$to form $\mathrm{TiO}_{2}$ nanotubes, reaction (8). 


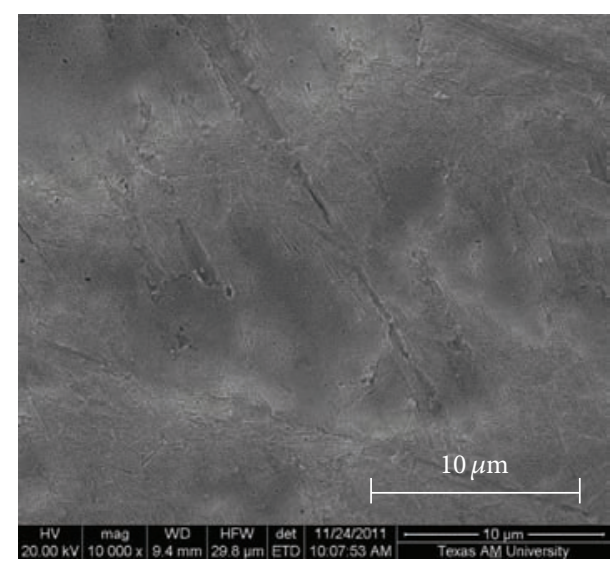

(a)

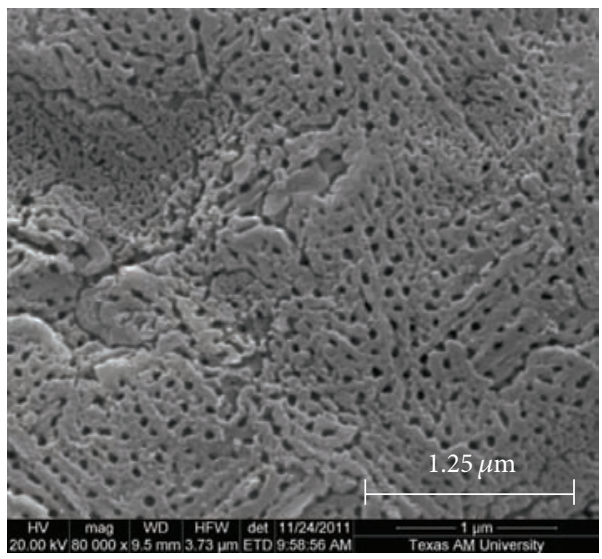

(c)

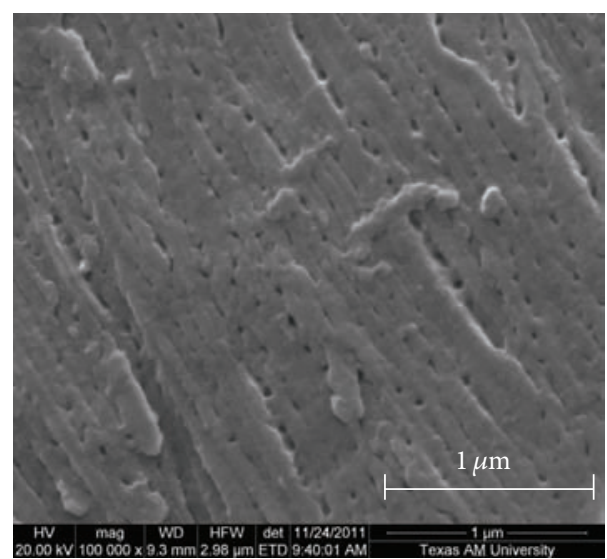

(b)

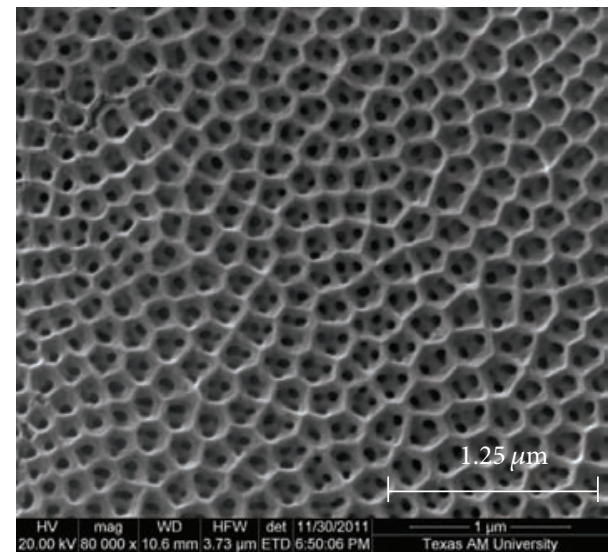

(d)

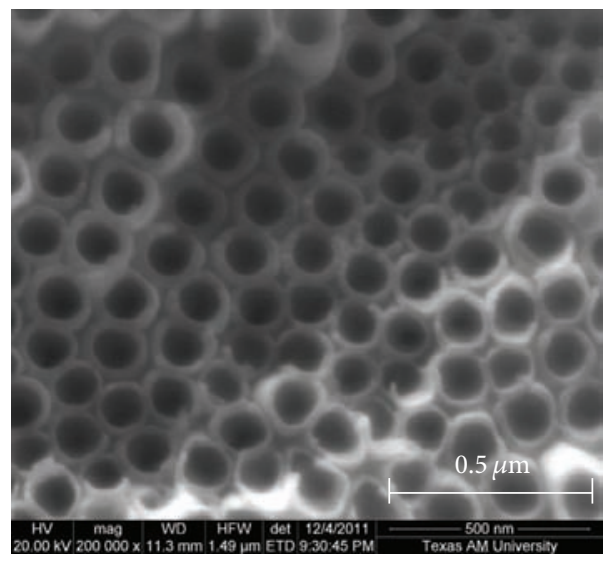

(e)

Figure 3: SEM images of Ti-Ta NT film structure: (a) compact layer, (b) partial porous film, (c) porous film, (d) net film, and (e) Ti-Ta NT.

Based on reactions (1)-(8), anodization of Ta can be described as

$$
\begin{gathered}
\mathrm{Ta} \longrightarrow \mathrm{Ta}^{5+}+5 \mathrm{e}^{-} \\
\mathrm{H}_{2} \mathrm{O} \longrightarrow 2 \mathrm{H}^{+}+\mathrm{O}^{2-} \\
2 \mathrm{Ta}^{5+}+5 \mathrm{O}^{2-} \longrightarrow \mathrm{Ta}_{2} \mathrm{O}_{5} \\
2 \mathrm{Ta}^{5+}+5 \mathrm{H}_{2} \mathrm{O} \longrightarrow 10 \mathrm{H}^{+}+\mathrm{Ta}_{2} \mathrm{O}_{5}
\end{gathered}
$$

$$
\begin{gathered}
12 \mathrm{~F}^{-}+2 \mathrm{Ta}_{2} \mathrm{O}_{5}+10 \mathrm{H}^{+} \longrightarrow 2\left[\mathrm{TaF}_{6}\right]^{-}+5 \mathrm{H}_{2} \mathrm{O} \\
2\left[\mathrm{TaF}_{6}\right]^{-}+2 n \mathrm{H}_{2} \mathrm{O} \longrightarrow 2\left[\mathrm{TaF}_{6-2 n}(\mathrm{OH})_{2 n}\right]^{-}+2 n \mathrm{H}^{+}+2 n \mathrm{~F}^{-} \\
2\left[\mathrm{TaF}_{6-2 n}(\mathrm{OH})_{2 n}\right]^{-}+(6-2 n) \mathrm{H}_{2} \mathrm{O} \\
\longrightarrow\left[\mathrm{Ta}(\mathrm{OH})_{6}\right]^{-}+(6-2 n) \mathrm{H}^{+}+(6-2 n) \mathrm{F}^{-} \\
2\left[\mathrm{Ta}(\mathrm{OH})_{6}\right]^{-}+2 \mathrm{H}^{+} \longrightarrow \mathrm{Ta}_{2} \mathrm{O}_{5}+7 \mathrm{H}_{2} \mathrm{O}
\end{gathered}
$$




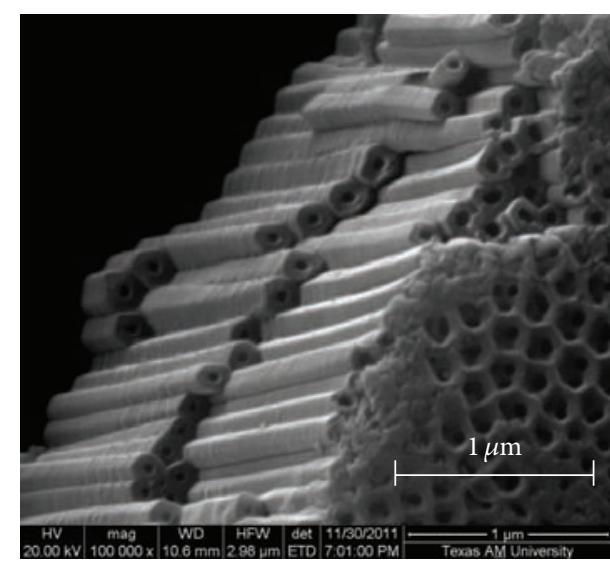

(a)

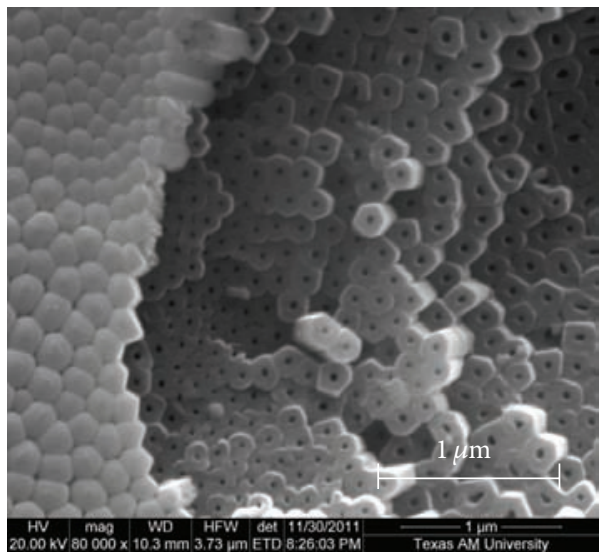

(c)

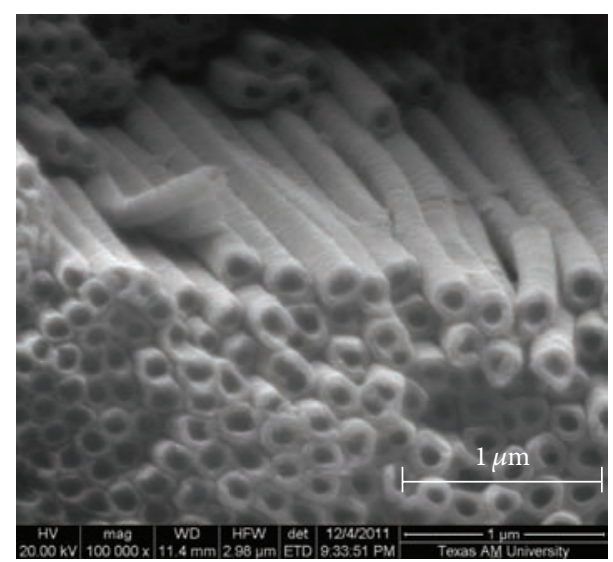

(b)

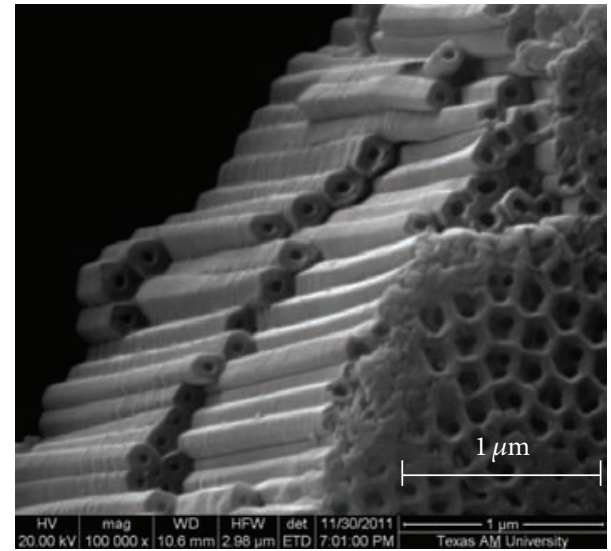

(d)

FIgURE 4: SEM images of $\mathrm{TiO}_{2}-\mathrm{Ta}_{2} \mathrm{O}_{5}$ nanotubes film by anodizing Ti-20Ta alloy: (a) a net film on the NT top, (b) without a net film on the NT top, (c) a barrier layer on the NT bottom, and (d) partial barrier layer on the NT bottom.

Also, anodization of Mo can be described as

$$
\begin{gathered}
\mathrm{Mo} \longrightarrow \mathrm{Mo}^{3+}+3 \mathrm{e}^{-} \\
\mathrm{H}_{2} \mathrm{O} \longrightarrow 2 \mathrm{H}^{+}+\mathrm{O}^{2-} \\
\mathrm{Mo}^{3+}+3 \mathrm{O}^{2-} \longrightarrow \mathrm{MoO}_{3} \\
\mathrm{Mo}^{3+}+3 \mathrm{H}_{2} \mathrm{O} \longrightarrow 6 \mathrm{H}^{+}+\mathrm{MoO}_{3} \\
6 \mathrm{~F}^{-}+\mathrm{MoO}_{3}+6 \mathrm{H}^{+} \longrightarrow\left[\mathrm{MoF}_{6}\right]^{3-}+3 \mathrm{H}_{2} \mathrm{O} \\
{\left[\mathrm{MoF}_{6}\right]^{3-}+n \mathrm{H}_{2} \mathrm{O} \longrightarrow\left[\mathrm{MoF}_{6-n}(\mathrm{OH})_{n}\right]^{3-}+n \mathrm{H}^{+}+n \mathrm{~F}^{-}} \\
{\left[\mathrm{MoF}_{6-n}(\mathrm{OH})_{n}\right]^{3-}+(6-n) \mathrm{H}_{2} \mathrm{O}} \\
\longrightarrow\left[\mathrm{Mo}(\mathrm{OH})_{6}\right]^{3-}+(6-n) \mathrm{H}^{+}+(6-n) \mathrm{F}^{-} \\
{\left[\mathrm{Mo}(\mathrm{OH})_{6}\right]^{3-}+3 \mathrm{H}^{+} \longrightarrow \mathrm{MoO}_{3}+3 \mathrm{H}_{2} \mathrm{O}}
\end{gathered}
$$

Figure 3 shows SEM images of $\mathrm{TiO}_{2}-\mathrm{Ta}_{2} \mathrm{O}_{5}$ nanotubes structure from anodizing Ti-10Ta alloy. There was a compact layer on the top of nanotubes in Figure 3(a). A continuous porous layer and grain boundary under the compact layer are observed in Figure 3(b). Figure 3(c) shows a porous film is covering the compact layer and following a net structure (Figure 3(d)) is covering the gap between ordered $\mathrm{TiO}_{2}$ $\mathrm{Ta}_{2} \mathrm{O}_{5}$ nanotubes (Figure 3(e)). There were extra continuous porous layers and net structures which were not presented on pure $\mathrm{TiO}_{2}$ nanotubes. The compact layer, continuous porous layer, and net structure were removed by $5 \mathrm{wt} . \%$ of $1 \mu \mathrm{m} \mathrm{Al}{ }_{2} \mathrm{O}_{3}$ powders in ethanol solvent assisted by ultrasonic vibration. Similar to Ti-10Ta alloy, Figure 4 shows SEM images of $\mathrm{TiO}_{2}-\mathrm{Ta}_{2} \mathrm{O}_{5}$ nanotube by anodizing Ti-20Ta alloy. Figure $4(\mathrm{a})$ shows a net film on the NT top, Figure 4(b) without a net film on the NT top, Figure 4(c) a barrier layer on the NT bottom, and Figure 4(d) partial barrier layer under the NT.

For the Ti-10Mo alloy, Figure 5(a) shows partially removed continuous porous layer on the net structure, larger pores on the top of $\mathrm{TiO}_{2}-\mathrm{MoO}_{3}$ nanotubes (Figure 5(b)), smaller pores (Figure 5(c)), and barrier layer (Figure 5(d)) on the bottom side. According to Figures 3-5, Figure 6 is a schematic diagram of anodic Ti alloy oxide structure with compact layer, continuous porous layer, net structure, and ordered nanotubes on the alloys surfaces.

Figure 7 shows a schematic structure and geometry of the Ti alloy oxide nanotube. Larger open pores are on the 


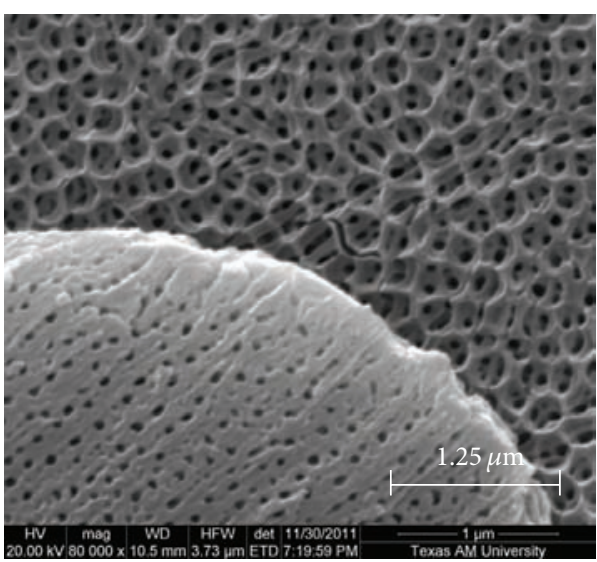

(a)

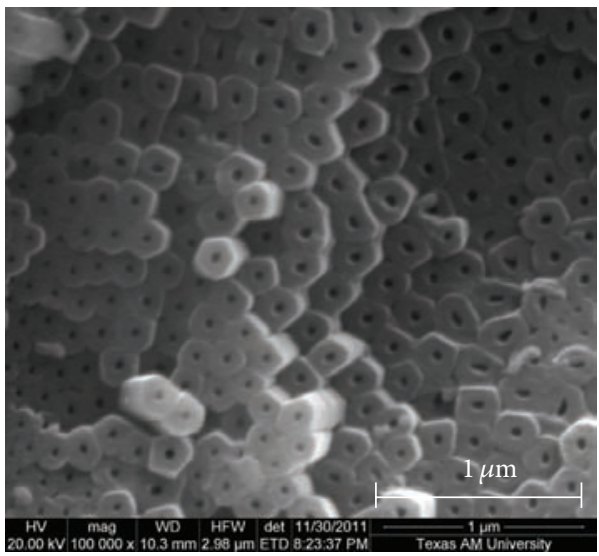

(c)

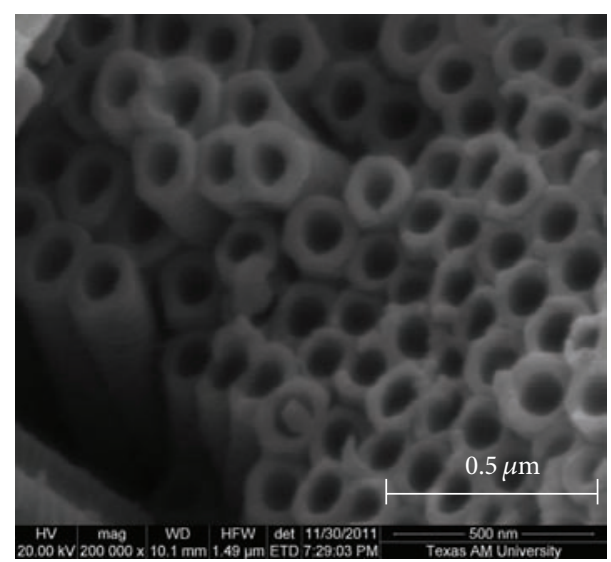

(b)

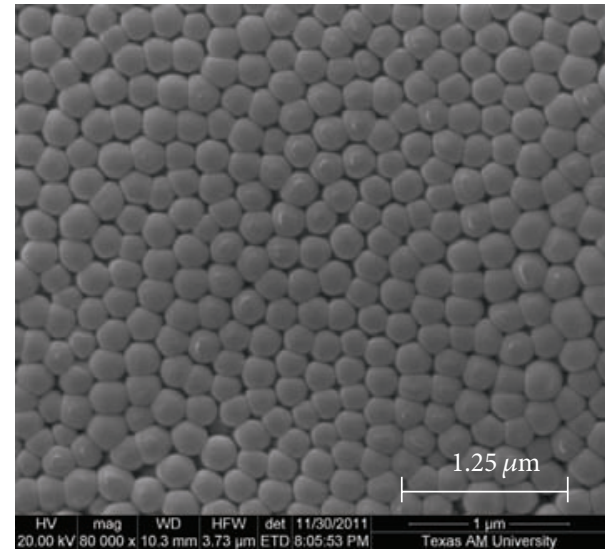

(d)

Figure 5: SEM images of $\mathrm{TiO}_{2}-\mathrm{MoO}_{3}$ nanotubes film by anodizing Ti-10Mo alloy: (a) a porous film and a net film on the NT top, (b) a cleaned NT top, (c) small pores on the NT bottom, and (d) a barrier layer on the NT bottom.

TABLE 1: EDS results of Ti alloys oxide nanotubes.

\begin{tabular}{lccc}
\hline & $\mathrm{TiO}_{2}(\%)$ & $\mathrm{Ta}_{2} \mathrm{O}_{5}(\%)$ & $\mathrm{MoO}_{3}(\%)$ \\
\hline $\mathrm{Ti}-20 \mathrm{Ta}$ & 83.9 & 16.1 & 0 \\
$\mathrm{Ti}-10 \mathrm{Ta}$ & 91.3 & 8.7 & 0 \\
$\mathrm{Ti}-10 \mathrm{Mo}$ & 92.8 & 0 & 7.2 \\
\hline
\end{tabular}

top (Figure 7(a)), smaller closed pores and a barrier layer in a hexagonal pattern are on the bottom side (Figure 7(b)), tube inner surface area (Figure $7(\mathrm{c})$ ), and outer surface area (Figure $7(\mathrm{~d})$ ). Denoting $R_{1}$ and $R_{2}$, and $T_{1}$ and $T_{2}$ are the radius and pores width of the top and bottom pores, respective, $W$ is the thickness of the outer barrier layer, and $H$ and $L$ is the inner height and total length of the nanotube. We have $R_{1}+T_{1}=R_{2}+T_{2}=R_{3}$, and total length of nanotube is $L=H+W$. Thus, the volume of a single alloy oxide can be calculated by $V=V_{\text {outer }}-V_{\text {inner }}$ where $V_{\text {outer }}$ and $V_{\text {inner }}$ can be obtained by

$$
\begin{gathered}
V_{\text {outer }}=\pi R_{3}^{2} \times L, \\
V_{\text {inner }}=\frac{1}{3} \pi \times \frac{H}{R_{1}-R_{2}} \times\left(R_{1}^{3}-R_{2}^{3}\right) .
\end{gathered}
$$

Based on the SEM images in Figures 3, 4, and 5, $R_{1}, R_{2}, R_{3}$, and $W$ were $60 \mathrm{~nm}, 25 \mathrm{~nm}, 80 \mathrm{~nm}$, and $40 \mathrm{~nm}$, respectively. For two hours anodization process, $20 \mu \mathrm{m}$ length of Ti alloy oxide nanotubes $(L)$ could be formed on the Ti alloy surface. Thus, $V_{\text {outer }}$ was $0.4 \mu \mathrm{m}^{3}$, and $V_{\text {inner }}$ was $0.12 \mu \mathrm{m}^{3}$, and the volume of a single alloy oxide nanotube $(V)$ was $0.28 \mu \mathrm{m}^{3}$. The $\mathrm{TiO}_{2}$ nanotubes density has been recently reported by Chen et al. [29] such that there are 4,510,548,978 nanotubes per $\mathrm{cm}^{2}$. Therefore, the total volume of Ti alloy nanotubes was $1.26 \times 10^{-3} \mathrm{~cm}^{3}$ in $1 \mathrm{~cm}^{2}$ sample area. Moreover, it has also been reported that nanotube surface area is greatly increased when $L=10 \mu \mathrm{m}, S_{\text {inner }}=120.5 \mathrm{~cm}^{2}, S_{\text {outer }}=$ $240.2 \mathrm{~cm}^{2}$ and $L=100 \mu \mathrm{m}, S_{\text {inner }}=1205 \mathrm{~cm}^{2}, S_{\text {outer }}=$ $2402 \mathrm{~cm}^{2}$. Figure 8 furthermore accumulated anodic Ti and Ti alloy NT inner and outer surface areas increased with film thickness increased based on $1 \mathrm{~cm}^{2}$ substrate. Hence, the extremely high surface area is able to provide more chances for electrochemical reactions.

According to the Pourbaix diagrams in Figure 2, anodizing Ti, Ti-20Ta, Ti-10Ta, and Ti-10Mo can form anodic oxide films of these Ti alloys. Therefore, the following alloy anodic oxide films densities are able to be calculated based on the $\mathrm{TiO}_{2}, \mathrm{Ta}_{2} \mathrm{O}_{5}$, and $\mathrm{MoO}_{3}$ densities of $4.2 \mathrm{~g} / \mathrm{cm}^{3}, 8.2 \mathrm{~g} / \mathrm{cm}^{3}$, and 
TABLE 2: Specific capacitance based on $\mathrm{TiO}_{2}$ NT, Ti-10Ta NT, Ti-20Ta NT, and Ti-10Mo NT films.

\begin{tabular}{lcccc}
\hline Sample size $\left(1 \mathrm{~cm}^{2} \times 20 \mu \mathrm{m}\right)$ & $\mathrm{TiO}_{2} \mathrm{NT}$ & $\mathrm{Ti}-10 \mathrm{Ta} \mathrm{NT}$ & $\mathrm{Ti}-20 \mathrm{Ta}$ NT & 3.65 \\
Density $\left(\mathrm{g} / \mathrm{cm}^{2}\right)$ & 3.09 & 3.19 & 7.30 & 3.07 \\
Mass of unit area $\left(\mathrm{mg} / \mathrm{cm}^{2}\right)$ & 6.18 & 6.38 & 143.30 & 6.14 \\
$d Q(\mathrm{mC})$ & 65.58 & 120.02 & 0.9 & 102.92 \\
$d E(\mathrm{~V})$ & 0.9 & 0.9 & 21.8 & 0.9 \\
Specific capacitance $(\mathrm{F} / \mathrm{g})$ & 11.8 & 20.9 & 18.6 \\
\hline
\end{tabular}

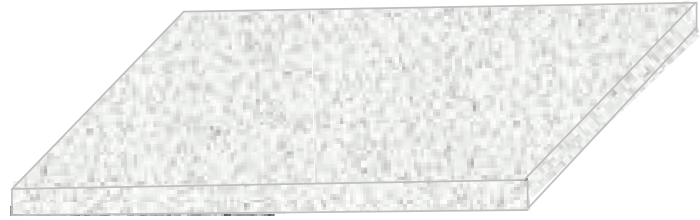

(a)

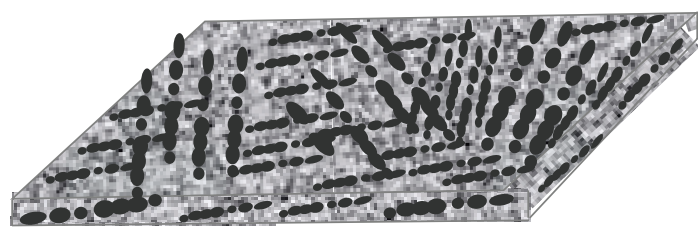

(b)

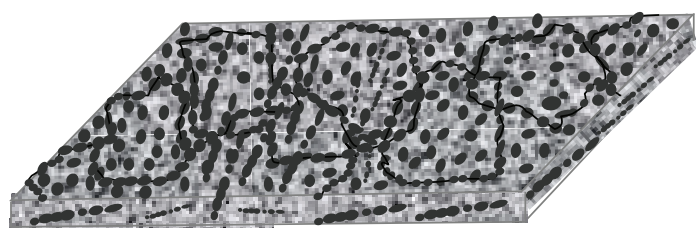

(c)

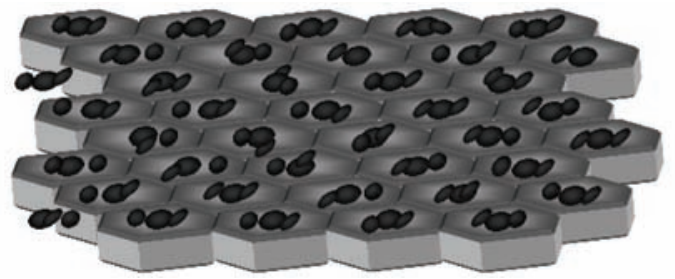

(d)

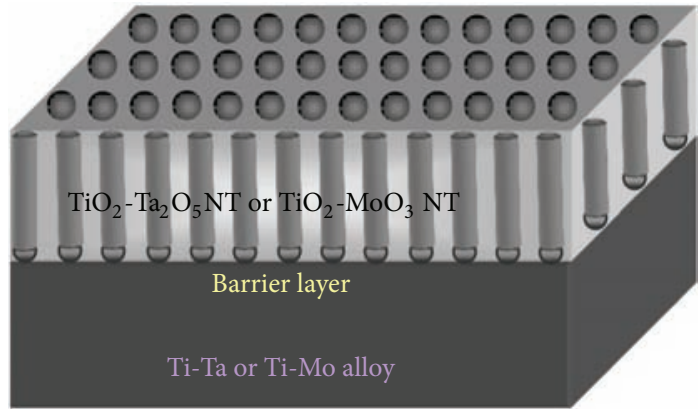

(e)

Figure 6: The schematic diagram of $\mathrm{TiO}_{2}-\mathrm{Ta}_{2} \mathrm{O}_{5} \mathrm{NT}$ or $\mathrm{TiO}_{2}-\mathrm{MoO}_{3}$ NT film structure: (a) compact layer, (b) partial porous film, (c) porous film, (d) net film, and (e) $\mathrm{TiO}_{2}-\mathrm{Ta}_{2} \mathrm{O}_{5} \mathrm{NT}$ or $\mathrm{TiO}_{2}-\mathrm{MoO}_{3}$ NT and barrier layer on the Ti-Ta or Ti-Mo alloy.
$4.7 \mathrm{~g} / \mathrm{cm}^{3}$, respectively. According to EDS results in Table 1, $\mathrm{Ti}$, Ti-20Ta, Ti-10Ta, and Ti-10Mo formed 100\% $\mathrm{TiO}_{2}, 83.9 \%$ $\mathrm{TiO}_{2}+16.1 \% \mathrm{Ta}_{2} \mathrm{O}_{5}, 91.3 \% \mathrm{TiO}_{2}+8.7 \% \mathrm{Ta}_{2} \mathrm{O}_{5}$, and $92.8 \%$ $\mathrm{TiO}_{2}+7.2 \% \mathrm{MoO}_{3}$. The densities of $100 \% \mathrm{TiO}_{2}, 83.9 \% \mathrm{TiO}_{2}+$ $16.1 \% \mathrm{Ta}_{2} \mathrm{O}_{5}, 91.3 \% \mathrm{TiO}_{2}+8.7 \% \mathrm{Ta}_{2} \mathrm{O}_{5}$, and $92.8 \% \mathrm{TiO}_{2}+$ $7.2 \% \mathrm{MoO}_{3}$ were $4.23 \mathrm{~g} / \mathrm{cm}^{3}, 4.84 \mathrm{~g} / \mathrm{cm}^{3}, 4.54 \mathrm{~g} / \mathrm{cm}^{3}$, and $4.24 \mathrm{~g} / \mathrm{cm}^{3}$, respectively. Therefore, the mass of nanotubes films $1 \mathrm{~cm}^{2}$ sample for each alloy was listed in Table 2 being $5.32 \mathrm{mg} / \mathrm{cm}^{2}, 6.09 \mathrm{mg} / \mathrm{cm}^{2}, 5.72 \mathrm{mg} / \mathrm{cm}^{2}$, and $5.34 \mathrm{mg} / \mathrm{cm}^{2}$.

Cyclic voltammograms $(\mathrm{CV})$ are used to characterize the capacitors behavior of the alloy oxide nanotubes. Figure 9 shows capacitance performance evaluations for the Ti alloy anodic oxide nanotubes by cyclic voltammograms. It is clear that $\mathrm{Ti}$ alloy oxide nanotubes had larger area of $\mathrm{CV}$ curve than pure $\mathrm{TiO}_{2}$ nanotube did. It means that $\mathrm{Ti}$ alloys oxide nanotubes had larger capacitances than pure $\mathrm{TiO}_{2}$ nanotubes. Besides, more $\mathrm{Ta}_{2} \mathrm{O}_{5}$ content can significantly enhance the capacitor performance by comparing two Ti-Ta alloys curves with different compositions. Moreover, Ti-10Mo alloy oxide nanotubes $\mathrm{CV}$ curve shows a symmetrical shape which indicates that the revisable redox reaction of $\mathrm{Mo}^{2+} / \mathrm{Mo}^{3+}$ was helpful to improve the capacitor performance. The specific capacitance $(C)$ can be measured by voltage step, current step, or voltage ramp methods and evaluated by the equations of $C=Q / V$ and $C=d Q / d V$ [35], where $V$ is applied voltage and $Q$ is the quantity of charge on the electrode (which can be evaluated from the area of the CV curve). Table 2 shows the specific capacitance based on $1 \mathrm{~cm}^{2}$ sample area and $20 \mu \mathrm{m}$ film thickness of pure Ti, Ti-20Ta, Ti-10Ta, and Ti-10Mo oxide nanotubes films which are $13.7 \mathrm{~F} / \mathrm{g}, 26.1 \mathrm{~F} / \mathrm{g}$, $23.3 \mathrm{~F} / \mathrm{g}$, and $21.4 \mathrm{~F} / \mathrm{g}$, respectively. The specific capacitances of $\mathrm{Ti}$ alloys oxide nanotubes films were higher than that of $\mathrm{TiO}_{2}-\mathrm{B}$ nanowires/MWCNTs hybrid supercapacitor with specific capacitance of $17.7 \mathrm{~F} / \mathrm{g}$ [36].

\section{Conclusions}

In summary, we fabricated ultracapacitors based on the working electrode made of highly ordered anodic $\mathrm{TiO}_{2}, \mathrm{Ta}_{2} \mathrm{O}_{5}$, and $\mathrm{MoO}_{3}$ nanotubes directly formed on pure Ti, Ti-20Ta, Ti-10Ta, and Ti-10Mo substrates. The ordered alloys oxide nanotubes structure has a volume of $1.26 \times 10^{-3} \mathrm{~cm}^{3}$ in $1 \mathrm{~cm}^{2}$ sample area with nanotube density of $4.5 \times 10^{9}$ tubes $/ \mathrm{cm}^{2}$. The mass of pure $\mathrm{Ti}$ and $\mathrm{Ti}$ alloys oxide nanotubes films with $1 \mathrm{~cm}^{2}$ sample size and $20 \mu \mathrm{m}$ film thickness can be calculated as $5.32 \mathrm{mg}$ ( $\mathrm{TiO}_{2}$ nanotubes), $6.09 \mathrm{mg}$ ( $\mathrm{Ti}-20 \mathrm{Ta}$ oxide nanotubes), $5.72 \mathrm{mg}$ (Ti-10Ta oxide nanotubes), and $5.34 \mathrm{mg}$ 


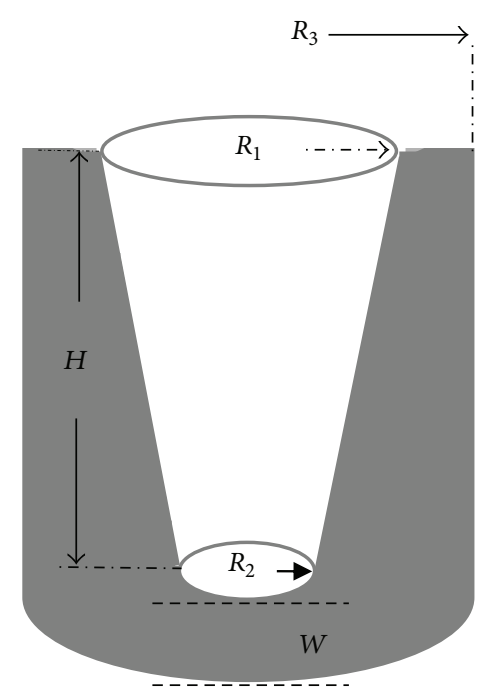

(a)

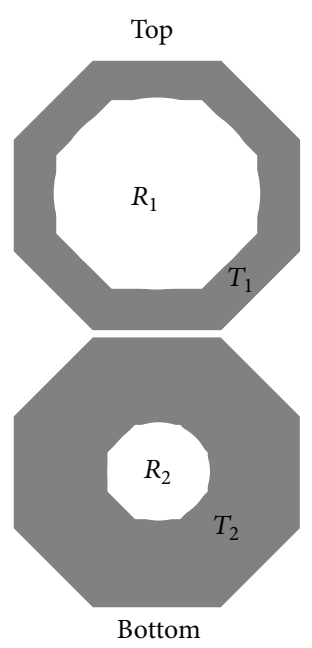

(b)

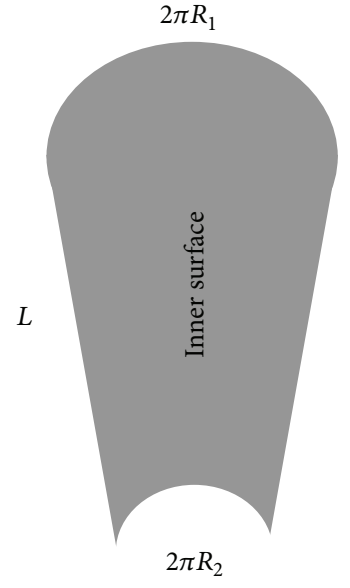

(c)

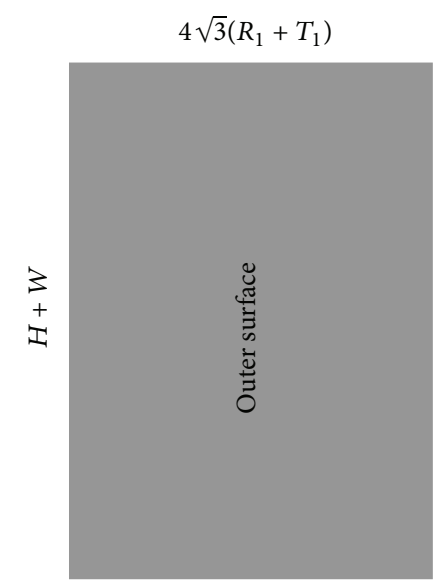

(d)
FIgURE 7: Estimation of $\mathrm{TiO}_{2}$ NT surface: (a) cone structure of inner tube with radius of $R_{3}$, and $R_{1}$, and $R_{2}$ on the tube top and bottom, tube length with $H$, (b) pore wall thickness with $T_{1}$ and $T_{2}$ on the tube top and bottom, (c) tube inner surface area, and (d) outer surface area.

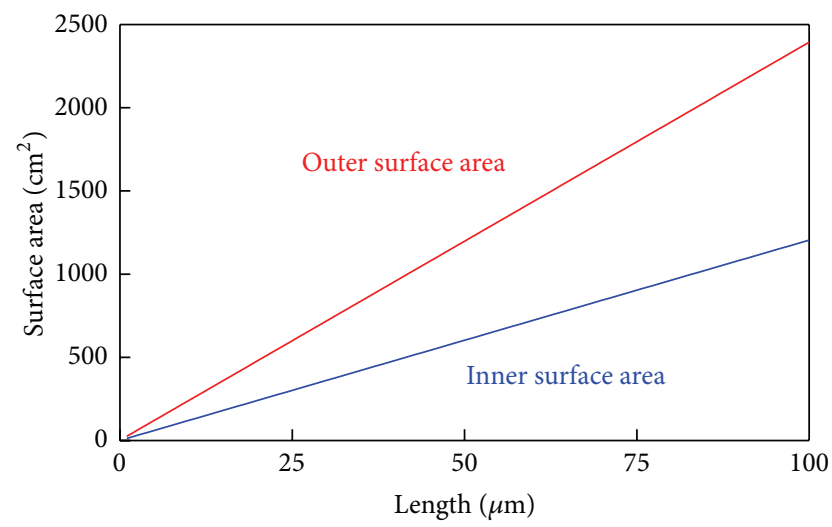

FIgUre 8: Accumulated anodic Ti and Ti alloy NT inner and outer surface areas based on $1 \mathrm{~cm}^{2}$ substrate.

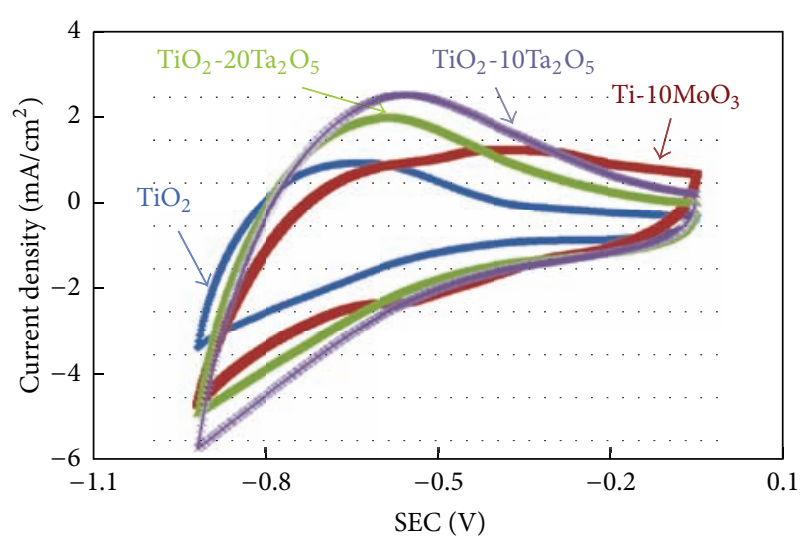

FIgure 9: Capacitance performance evaluations for $\mathrm{TiO}_{2} \mathrm{NT}, \mathrm{TiO}_{2}$ $10 \mathrm{Ta}_{2} \mathrm{O}_{5} \mathrm{NT}, \mathrm{TiO}_{2}-20 \mathrm{Ta}_{2} \mathrm{O}_{5} \mathrm{NT}$, and $\mathrm{TiO}_{2}-10 \mathrm{MoO}_{3} \mathrm{NT}$ by cyclic voltammograms.

(Ti-10Mo oxide nanotubes), respectively. Furthermore, Ti alloy anodic oxide nanotubes films with $1 \mathrm{~cm}^{2}$ surface and $20 \mu \mathrm{m}$ thickness have an inner surface area of $241.0 \mathrm{~cm}^{2}$ and outer surface area of $480.4 \mathrm{~cm}^{2}$. Thus, such large surface area of dielectric oxides caused very high specific capacitances. The specific capacitance can further be enhanced by (1) reacting with barium nitrate $\left(\mathrm{Ba}\left(\mathrm{NO}_{3}\right)_{2}\right)$ [37] or barium hydroxide $\left(\mathrm{Ba}(\mathrm{OH})_{2}\right)$ [38] to form a very high dielectric constant $\mathrm{BaTiO}_{3}$ film, (2) increasing nanotubes length by longer anodization process, and (3) increasing nanotubes surface area by coating $\mathrm{TiO}_{2}$ nanoparticles on the nanotubes surface [39].

\section{Acknowledgment}

This study was partially supported by a Grant from the National Science Council, Taiwan (102-3113-P-042A-005-).

\section{References}

[1] L. E. Cross, "Ferroelectric materials for electromechanical transducer applications," Materials Chemistry and Physics, vol. 43, no. 2, pp. 108-115, 1996.

[2] A. D. Hilton and R. Frost, "Recent developments in the manufacture of barium titanate powders," Key Engineering Materials, vol. 66, pp. 145-184, 1992.

[3] L. E. Cross, "Dielectric, piezoelectric and ferroelectric components," American Ceramic Society Bulletin, vol. 63, no. 4, pp. 586-590, 1984.

[4] D. Pandey, A. P. Singh, and V. S. Tiwari, "Developments in ferroelectric ceramics for capacitor applications," Bulletin of Materials Science, vol. 15, no. 5, pp. 391-402, 1992.

[5] K. Kajiyoshi, N. Ishizawa, and M. Yoshimura, "Preparation of tetragonal barium titanate thin film on titanium metal substrate by hydrothermal method," Journal of the American Ceramic Society, vol. 74, no. 2, pp. 369-374, 1991.

[6] T. Horikawa, N. Mikami, T. Makita et al., "Dielectric properties of ( $\mathrm{Ba}, \mathrm{Sr}) \mathrm{TiO}_{3}$ thin films deposited by RF sputtering," Japanese Journal of Applied Physics, vol. 32, no. 9, pp. 4126-4130, 1993. 
[7] A. S. Shaikh and G. M. Vest, "Kinetics of $\mathrm{BaTiO}_{3}$ and $\mathrm{PbTiO}_{3}$ formation from metallo-organic precursors," Journal of the American Ceramic Society, vol. 69, no. 9, pp. 682-688, 1986.

[8] H. Okamura and H. K. Bowen, "Preparation of alkoxides for the synthesis of ceramics," Ceramics International, vol. 12, no. 3, pp. 161-171, 1986.

[9] K. W. Kirby, "Alkoxide synthesis techniques for $\mathrm{BaTiO}_{3}$," Materials Research Bulletin, vol. 23, no. 6, pp. 881-890, 1988.

[10] P. Bhattacharya, T. Komeda, K.-H. Park, and Y. Nishioka, "Comparative study of amorphous and crystalline (Ba, $\mathrm{Sr}) \mathrm{TiO}_{3}$ thin films deposited by laser ablation," Japanese Journal of Applied Physics, vol. 32, no. 9, pp. 4103-4106, 1993.

[11] D. M. Tahan, A. Safari, and L. C. Klein, "Preparation and characterization of $\mathrm{Ba}_{x} \mathrm{Sr}_{1-x} \mathrm{TiO}_{3}$ thin films by a Sol-Gel technique," Journal of the American Ceramic Society, vol. 79, no. 6, pp. 15931598, 1996.

[12] C.-C. Chen, J.-H. Chen, C.-G. Chao, and W. C. Say, "Electrochemical characteristics of surface of titanium formed by electrolytic polishing and anodizing," Journal of Materials Science, vol. 40, no. 15, pp. 4053-4059, 2005.

[13] C.-C. Chen, Y. Bisrat, Z. P. Luo, R. E. Schaak, C.-G. Chao, and D. C. Lagoudas, "Fabrication of single-crystal tin nanowires by hydraulic pressure injection," Nanotechnology, vol. 17, no. 2, pp. 367-374, 2006.

[14] H. Tsuchiya and P. Schmuki, "Self-organized high aspect ratio porous hafnium oxide prepared by electrochemical anodization," Electrochemistry Communications, vol. 7, no. 1, pp. 49-52, 2005.

[15] I. Sieber, H. Hildebrand, A. Friedrich, and P. Schmuki, "Formation of self-organized niobium porous oxide on niobium," Electrochemistry Communications, vol. 7, no. 1, pp. 97-100, 2005.

[16] I. Sieber, B. Kannan, and P. Schmuki, "Self-assembled porous tantalum oxide prepared in $\mathrm{H}_{2} \mathrm{SO}_{4} / \mathrm{HF}$ electrolytes," Electrochemical and Solid-State Letters, vol. 8, no. 3, pp. J10-J12, 2005.

[17] N. Mukherjee, M. Paulose, O. K. Varghese, G. K. Mor, and C. A. Grimes, "Fabrication of nanoporous tungsten oxide by galvanostatic anodization," Journal of Materials Research, vol. 18, no. 10, pp. 2296-2299, 2003.

[18] G. B. Stefanovich, A. L. Pergament, A. A. Velichko, and L. A. Stefanovich, "Anodic oxidation of vanadium and properties of vanadium oxide films," Journal of Physics: Condensed Matter, vol. 16, no. 23, pp. 4013-4024, 2004.

[19] N. K. Shrestha, Y.-C. Nah, H. Tsuchiya, and P. Schmuki, "Self-organized nano-tubes of $\mathrm{TiO}_{2}-\mathrm{MoO}_{3}$ with enhanced electrochromic properties," Chemical Communications, no. 15, pp. 2008-2010, 2009.

[20] I. Paramasivam, Y.-C. Nah, C. Das, N. K. Shrestha, and P. Schmuki, " $\mathrm{WO}_{3} / \mathrm{TiO}_{2}$ nanotubes with strongly enhanced photocatalytic activity," Chemistry - A European Journal, vol. 16, no. 30, pp. 8993-8997, 2010.

[21] A. Ghicov, S. Aldabergenova, H. Tsuchyia, and P. Schmuki, " $\mathrm{TiO}_{2}-\mathrm{Nb}_{2} \mathrm{O}_{5}$ nanotubes with electrochemically tunable morphologies," Angewandte Chemie-International Edition, vol. 45, no. 42, pp. 6993-6996, 2006.

[22] Y. Yang, D. Kim, M. Yang, and P. Schmuki, "Vertically aligned mixed $\mathrm{V}_{2} \mathrm{O}_{5}-\mathrm{TiO}_{2}$ nanotube arrays for supercapacitor applications," Chemical Communications, vol. 47, no. 27, pp. 7746-7748, 2011.

[23] H. Jha, R. Hahn, and P. Schmuki, "Ultrafast oxide nanotube formation on TiNb, TiZr and TiTa alloys by rapid breakdown anodization," Electrochimica Acta, vol. 55, no. 28, pp. 8883-8887, 2010.
[24] W. Wei, S. Berger, N. Shrestha, and P. Schmuki, "Ideal hexagonal order: formation of self-organized anodic oxide nanotubes and nanopores on a Ti-35Ta alloy," Journal of the Electrochemical Society, vol. 157, no. 12, pp. C409-C413, 2010.

[25] H. Tsuchiya, S. Berger, J. M. Macak, A. Ghicov, and P. Schmuki, "Self-organized porous and tubular oxide layers on TiAl alloys," Electrochemistry Communications, vol. 9, no. 9, pp. 2397-2402, 2007.

[26] R. J. D. Tilley, "Correlation between dielectric constant and defect structure of non-stoichiometric solids," Nature, vol. 269, no. 5625, pp. 229-231, 1977.

[27] J. Lin, N. Masaaki, A. Tsukune, and M. Yamada, " $\mathrm{Ta}_{2} \mathrm{O}_{5}$ thin films with exceptionally high dielectric constant," Applied Physics Letters, vol. 74, no. 16, pp. 2370-2372, 1999.

[28] H. Segawa, K. Mori, M. Itagati, K. Sakurki, and T. Ishiwta, "Image sensing device," US patent no. 4499384, 1985.

[29] C. C. Chen, D. Fang, and Z. Luo, "Fabrication and characterization of highly-ordered valve-metal oxide nanotubes and their derivative nanostructures," Reviews in Nanoscience and Nanotechnology, vol. 1, no. 4, pp. 1-28, 2012.

[30] M. Pourbaix, Atlas of Electrochemical Equilibria in Aqueous Solutions, NACE, Houston, Tex, USA, 1974.

[31] C. W. Lai and S. Sreekantan, "Effect of applied potential on the formation of self-organized $\mathrm{TiO}_{2}$ nanotube arrays and its photoelectrochemical response," Journal of Nanomaterials, vol. 2011, Article ID 142463, 7 pages, 2011.

[32] J. H. Lim and J. Choi, "Titanium oxide nanowires originating from anodically grown nanotubes: the bamboo-splitting model," Small, vol. 3, no. 9, pp. 1504-1507, 2007.

[33] J. Tao, J. Zhao, X. Wang, Y. Kang, and Y. Li, "Fabrication of titania nanotube arrays on curved surface," Electrochemistry Communications, vol. 10, no. 8, pp. 1161-1163, 2008.

[34] D. Kim, F. Schmidt-Stein, R. Hahn, and P. Schmuki, "Gravity assisted growth of self-organized anodic oxide nanotubes on titanium," Electrochemistry Communications, vol. 10, no. 7, pp. 1082-1086, 2008.

[35] A. J. Bard and L. R. Faulkner, Electrochemical Methods, Fundamentals and Applications, John Wiley \& Sons, Singapore, 1980.

[36] G. Wang, Z. Y. Liu, J. N. Wu, and Q. Lu, "Preparation and electrochemical capacitance behavior of $\mathrm{TiO}_{2}-\mathrm{B}$ nanotubes for hybrid supercapacitor," Materials Letters, vol. 71, pp. 120-122, 2012.

[37] L. Zhang, Y. Shi, S. Peng, J. Liang, Z. Tao, and J. Chen, "Dyesensitized solar cells made from $\mathrm{BaTiO}_{3}$-coated $\mathrm{TiO}_{2}$ nanoporous electrodes," Journal of Photochemistry and Photobiology A, vol. 197, no. 2-3, pp. 260-265, 2008.

[38] X. Wei, "Hydrothermal synthesis of $\mathrm{BaTiO}_{3}$ thin films on nanoporous $\mathrm{TiO}_{2}$ covered Ti substrates," Journal of Crystal Growth, vol. 286, no. 2, pp. 371-375, 2006.

[39] C.-C. Chen, H.-W. Chung, C.-H. Chen et al., "Fabrication and characterization of anodic titanium oxide nanotube arrays of controlled length for highly efficient dye-sensitized solar cells," Journal of Physical Chemistry C, vol. 112, no. 48, pp. 19151-19157, 2008. 

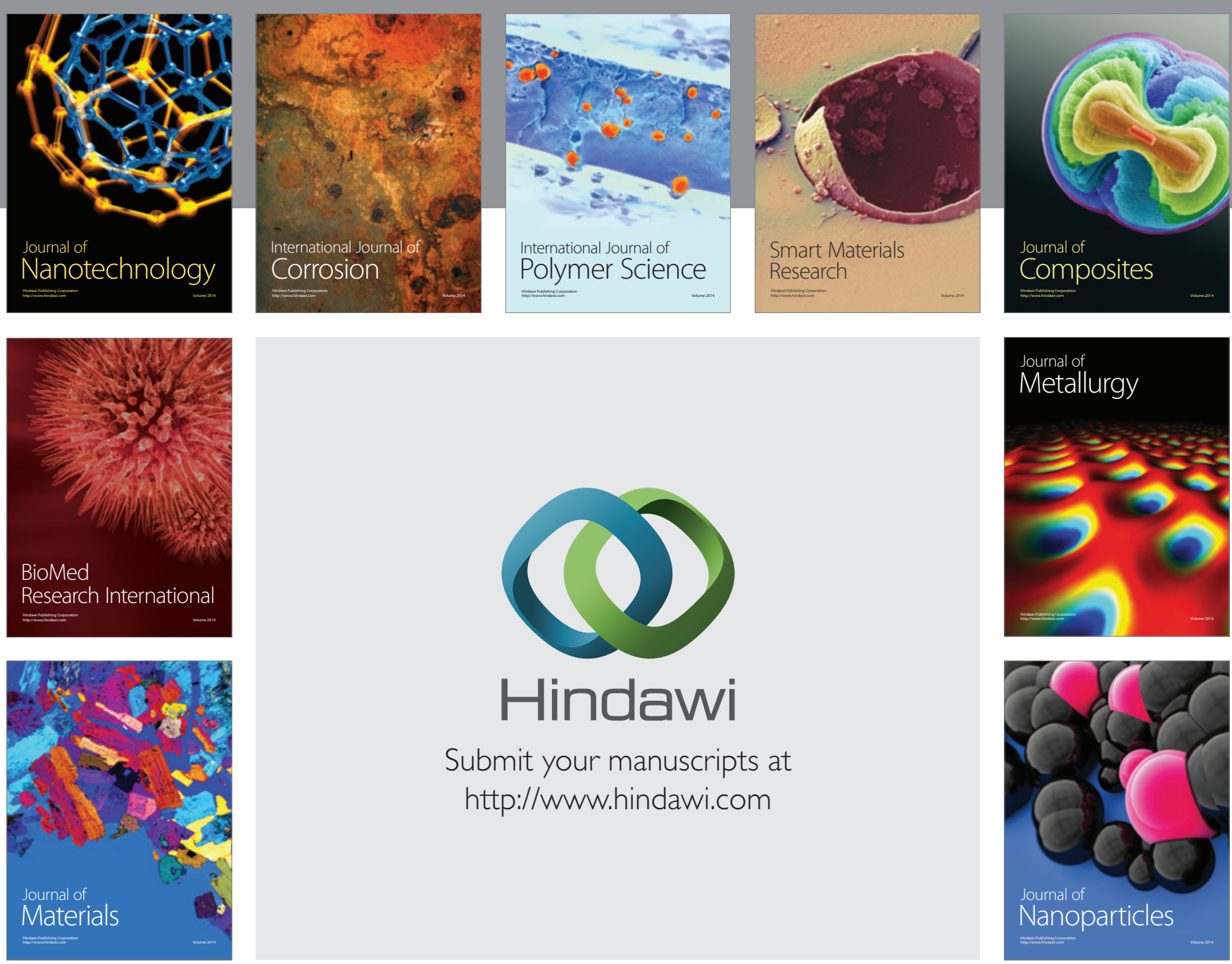

Submit your manuscripts at http://www.hindawi.com
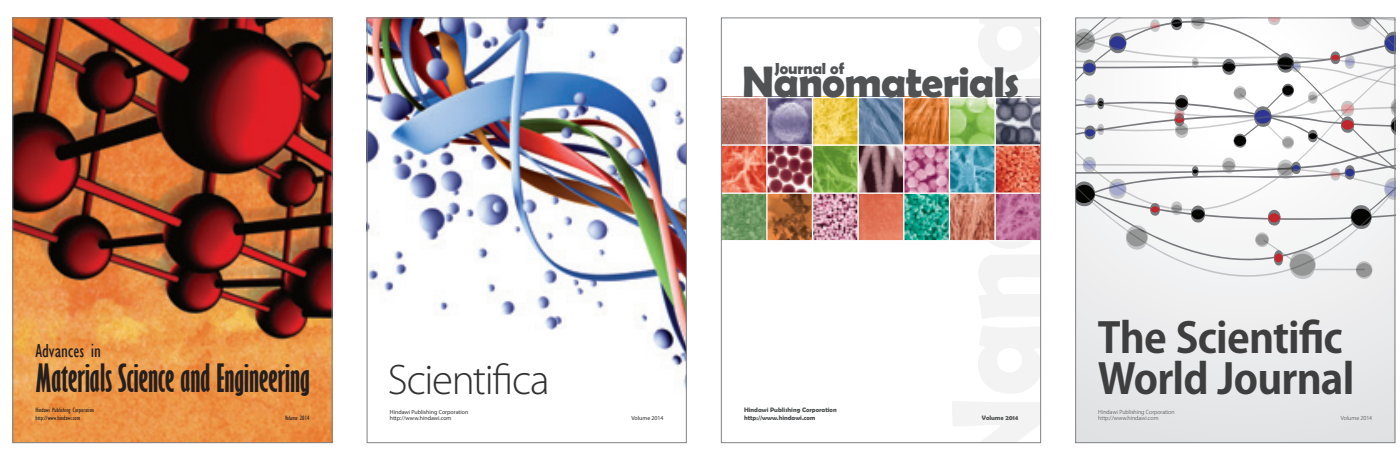

\section{The Scientific World Journal}
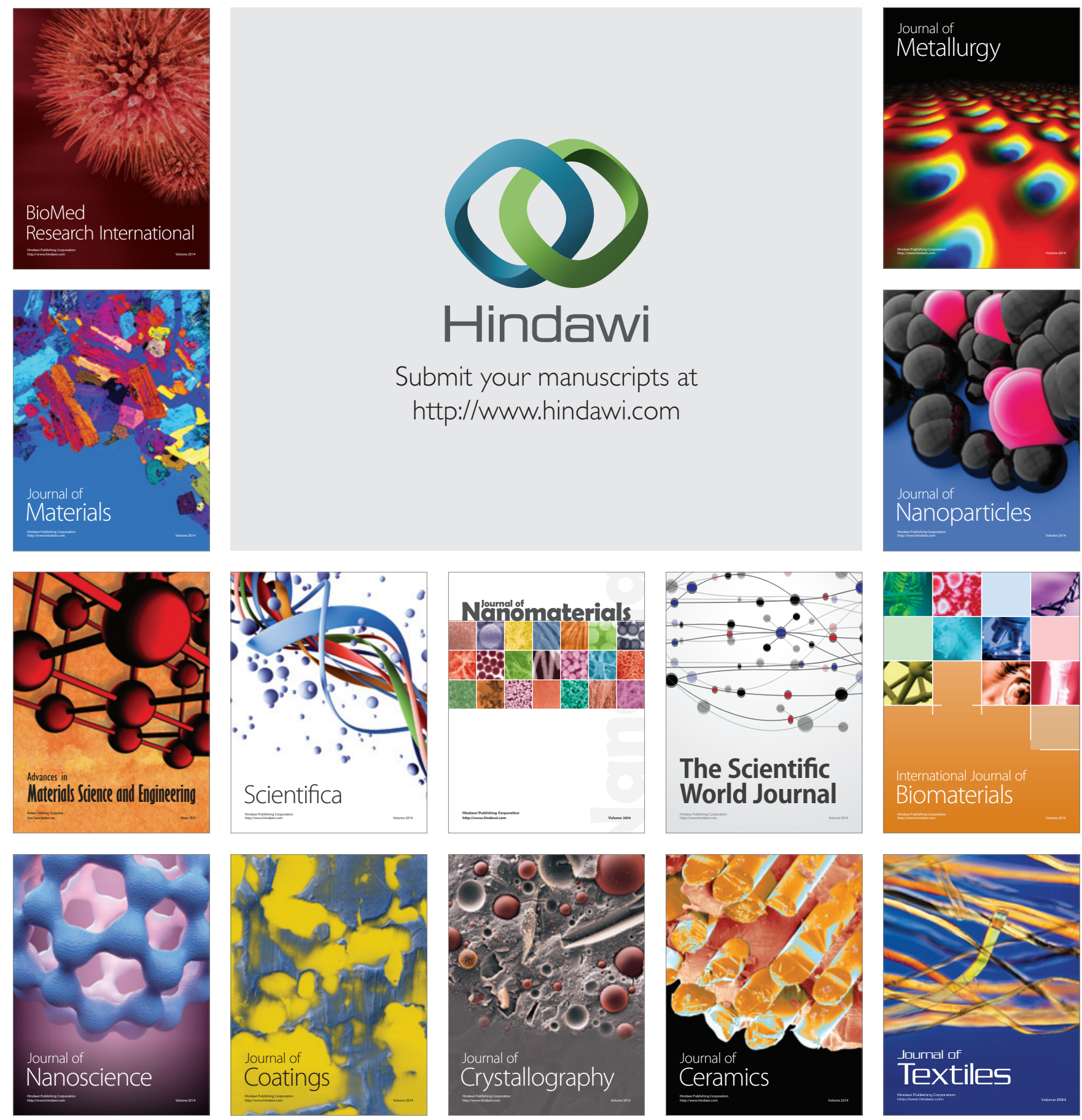